\title{
Selective activation of oncogenic Ha-ras-induced apoptosis in NIH/3T3 cells
}

\author{
H-S Liu, C-Y Chen, C-H Lee and Y-I Chou \\ Department of Microbiology and Immunology, College of Medicine, National Cheng Kung University, Tainan, Taiwan, Republic of China
}

\begin{abstract}
Summary A Ha-ras transformant '7-4', derived from mouse NIH/3T3 fibroblasts, was used to study the relationship between overexpression of activated Ha-ras and cell apoptosis. This cell line contains an inducible Ha-ras ${ }^{\mathrm{Val12}}$ oncogene, which was under the regulation of the Escherichia coli (E. coli) lac operator/repressor system. We demonstrate that overexpression of activated Ha-ras oncogene by exogenous isopropyl- $\beta$-D-thiogalactoside (IPTG) under serum-depleted conditions can stimulate cell apoptosis. Cell cycle analysis showed that most of the 7-4 cells with Ha-ras overexpression accumulated at S-phase and that the expression level of p34coc2 kinase was decreased, suggesting that p34cdc2 may be involved in 7-4 cell apoptosis. Overexpression of bcl-2 transgene in these cells blocked Ha-ras-induced apoptosis, and this blockage was confirmed downstream of Ha-ras gene expression. Cycloheximide blocked the apoptosis of 7-4 cells in a dose-dependent manner, indicating that specific protein regulating apoptosis may be synthesized through Ha-ras overexpression. Ha-ras overexpressiontriggered apoptosis was also prevented in the 7-4 derivatives that express either dominant-negative ras ${ }^{A s n 17}$ or dominant-negative raf-1 ${ }^{\mathrm{CAB}}$ to suppress Ha-ras signal transduction at different stages, indicating that overexpression of activated Ha-ras can induce cell apoptosis and that raf-1 pathway activity is required for this process.
\end{abstract}

Keywords: Ha-ras; bct-2; raf-1; apoptosis

Three ras proto-oncogenes ( $\mathrm{H}-, \mathrm{K}$ - and $\mathrm{N}$-ras) in the ras family are found in the mammalian genome (Downward, 1992). The activated ras oncogenes (such as the viral v-ras oncogenes) that are derived from normal cellular proto-oncogenes and activated by the mutations at amino acid position 12 and several other sites are the most frequently identified oncogenes in human neoplasia, indicating that ras oncogenes play an important role in the process of carcinogenesis (Barbacid, 1987). Extensive studies have demonstrated that cell proliferation and differentiation are dependent upon Ras. This includes the raf-1 product and the mitogen-activated protein (MAP) kinase. In recent studies, several investigators have suggested that the role of activated ras oncogenes in the process of carcinogenesis is to provide cells with not only a selective proliferation function but also an antiapoptotic function (Sakai et al, 1994). Arends et al (1994) reported that transfectants with moderate or high oncogenic Ha-ras val12 expression showed reduced apoptosis. Several reports have also suggested that expression of oncogenic ras has the ability to prevent apoptosis and increase cell survival to anti-cancer drugs or ionizing radiation at doses that demonstrate apoptosis (Arends et al, 1993; Sakai et al, 1994; Jimenez et al, 1995). Conversely, some reports have recently demonstrated that Ha-ras oncogene overexpression could induce apoptosis, which includes promoting the sensitivity of murine fibroblast $10 \mathrm{~T} 1 / 2$ cells to apoptosis induced by tumour necrosis factor, inducing apoptosis of Jurkat cells after suppression of protein kinase C (PKC) activity (Chen and Faller, 1996) and triggering apoptosis of REF cells in the presence of the IRF-1 gene (Tanaka et al, 1994). Moreover, it is found that Ha-ras is an

Received 7 May 1997

Revised 29 October 1997

Accepted 4 November 1997

Correspondence to: HS Liu effective promoter of apoptosis through the Raf pathway, whereas c-myc was found to be overexpressed under serum-deprived conditions (Kauffmann-Zeh et al, 1997).

Furthermore, Fas ligation-induced apoptosis in immune homeostasis needs normal ras activation (Gulbins et al, 1995). In the ras superfamily, overexpression of normal rho-p21 or activated R-Ras induces apoptosis in NIH/3T3 cells after serum deprivation (Jimenez et al, 1995; Wang et al, 1995). Thus, either normal or activated ras genes from the ras family or the ras superfamily may be involved in apoptosis. The mechanisms of their action may differ from one cell system to another. It is possible that the effects depend on the status of other genes known to regulate apoptosis (such as bcl-2, c-myc and p53) (Fernandez et al, 1995).

In this report, a NIH/3T3 derivative designated 7-4 containing an inducible Ha-ras ${ }^{\text {val12 }}$ oncogene regulated by an Escherichia coli lac repressor was used to demonstrate that Ha-ras overexpression can indeed trigger apoptosis by manipulating the inducer of isopropyl- $\beta$-D-thiogalactoside (IPTG). This apoptosis was further confirmed by dominant-negative ras $^{\mathrm{Asn} 17}$ and raf-1 ${ }^{\mathrm{C4B}}$ studies.

\section{MATERIALS AND METHODS}

\section{Cell culture}

Mouse fibroblast NIH/3T3 cells and their transgenic derivatives (7-4, 7-4-2 and dominant-negative ras and raf-1 cells) were maintained in $\alpha$-modified Eagle medium ( $\alpha$-MEM; Gibco-BRL, USA) containing $10 \%$ calf serum (Gibco) and incubated at $37^{\circ} \mathrm{C}$ in a carbon dioxide incubator. The 7-4 cells contain plasmids pSVlacOras and p3'SS (Stratagene, USA) (Liu et al, 1992; Ducoeur et al, 1993); and 7-4-2 cells, a derivative of 7-4 cells, contain the third plasmid pC $\Delta \mathrm{J}-b c l-2$ (Tsujimoto, 1989). IPTG (Gold biotechnology, USA), a non-metabolizable lactose analogue, was added to induce expression of Ha-ras transgene in 7-4 and 7-4-2 cells. 


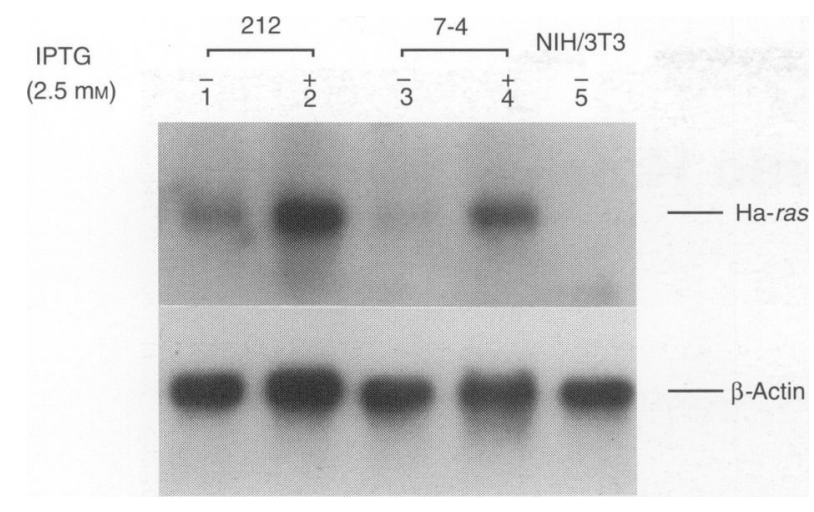

Figure 1 Ha-ras oncogene was overexpressed in 7-4 and 212 cells by IPTG induction under serum-deprived conditions. The cells were maintained in $0.2 \%$ calf serum-containing medium in the absence or presence of $2.5 \mathrm{~mm}$ IPTG for $48 \mathrm{~h}$. Total RNA was then extracted and electrophoresed on a $1 \%$ glyoxal gel. The probes used were an [ $\left.\alpha-{ }^{32} \mathrm{P}\right] \mathrm{dCTP}$-labelled 4-kb BamHI fragment of Ha-ras DNA from plasmid pSVlacOras and a 2-kb BamHI fragment of $\beta$-actin DNA from plasmid pHFBA-1 (Liu et al, 1992). $\beta$-Actin is used as an internal control

Table 1 Ha-ras gene overexpression caused accumulation of 7-4 cells at S-phase under $0.2 \%$ serum condition

\begin{tabular}{lrcc}
\hline Cell cycle & NIH/3T3 & $\mathbf{7 - 4}$ & $\mathbf{7 - 4 ~ I P T G}$ \\
\hline $\mathrm{G}_{0} / \mathrm{G}_{1}$ & $88 \%$ & $48 \%$ & $51 \%$ \\
$\mathrm{~S}$ & $9 \%$ & $48 \%$ & $90 \%$ \\
\hline
\end{tabular}

$\mathrm{NIH} / 3 \mathrm{~T} 3$ and $7-4$ cells were cultured in $0.2 \%$ serum-containing medium for $24 \mathrm{~h}$. IPTG (2.5 mM) was then added and the cells were harvested at 24-h intervals. This table shows the result of $72 \mathrm{~h}$ post-IPTG treatment. A total of 5000 cells were analysed using flow cytometry.

\section{DNA transfection}

Cells $\left(2 \times 10^{5}\right)$ in a 60 -mm plate were co-transfected with the desired reporter plasmids (1.5-3 $\mu \mathrm{g}$ per plate) and pSG5lacZ $\beta$ galactosidase reporter gene $(0.5 \mu \mathrm{g}$ per plate) as the internal control using the Lipofectin method (Gibco-BRL) for $5 \mathrm{~h}$. $\beta$ Galactosidase activity was determined to calibrate the transfection efficiencies. The cells were harvested and analysed $48 \mathrm{~h}$ after transfection.

\section{Microassay for cell viability}

The microassay for cell viability was performed as described previously (Ito, 1984). Briefly, cells were seeded in the 96-well flat-bottom microplates (Nunc, Denmark) at appropriate concentrations (1-1.5 $\times 10^{4}$ cells per $100 \mu$ per well) and incubated at $37^{\circ} \mathrm{C}$ in a carbon dioxide incubator for $4 \mathrm{~h}$ for cell attachment. The medium was then replaced with fresh medium. Eight wells were used for each treatment. At the end of the incubation, the medium was removed and the cells in wells were then fixed with $10 \%$ formalin $(50 \mu \mathrm{l}$ per well) for $10 \mathrm{~min}$, after which they were stained with $0.05 \%$ crystal violet ( $30 \mu \mathrm{l}$ per well) for $30 \mathrm{~min}$. The stained microplates were rinsed with tap water and then air dried. For the determination of cell viability, colorimetry was used. The elution fluid containing $50 \%$ ethanol and $0.1 \%$ acetic acid $(150 \mu \mathrm{l}$ per well) was added to each well, and the eluted blue dye in each well was quantified by optical density measured at $590 \mathrm{~nm}\left(\mathrm{OD}_{590}\right)$ with a Dynatech MR5000 microplate reader (Dynatech laboratories, VA, USA). The percentage of inhibition was calculated according to the following equation:

$\begin{aligned} & \text { Per cent } \\ & \text { inhibition }\end{aligned}=100 \times \frac{\mathrm{OD}_{590}(\text { sample })-\mathrm{OD}_{590}(\text { medium control })}{\mathrm{OD}_{590}(\text { cell control })-\mathrm{OD}_{590}(\text { medium control })}$

\section{Northern blot analysis}

Thirty micrograms of total RNA prepared from the cells was loaded into the wells on a $1 \%$ agarose gel containing $5 \mathrm{M}$ glyoxal. The RNA was fractionated by electrophoresis at $80 \mathrm{~V}, 80 \mathrm{~mA}$, for $2 \mathrm{~h}$, transferred to a Hybond- $\mathrm{N}$ transfer membrane in $25 \mathrm{~mm}$ sodium phosphate, $\mathrm{pH} 6.5$, and hybridized with the probes labelled with $[\alpha-32 \mathrm{P}] \mathrm{dCTP}$ to a specific activity of $4 \times 10^{8} \mathrm{dpm}_{\mu \mathrm{g}}^{-1}$ by random priming (Sambrook et al, 1989). The blot was exposed to Kodak X-OMAT AR film with the intensifying screen before development (Liu et al, 1992).

\section{Western blot analysis}

Fifteen micrograms of total protein from the cells was denatured in sodium dodecyl sulphate (SDS) lysis buffer $(50 \mathrm{~mm}$ Tris- $\mathrm{HCl}$, $\mathrm{pH} 6.8,2 \%$ SDS, $10 \%$ glycerol and $100 \mathrm{~mm}$ dithiothreitol) and loaded into duplicated $12 \%$ SDS-polyacrylamide gels. After electrophoresis at $100 \mathrm{~V}$ for $3 \mathrm{~h}$ in SDS-PAGE running buffer $(25 \mathrm{~mm}$ Tris- $\mathrm{HCl}, \mathrm{pH} 8.8,250 \mathrm{~mm}$ glycine, $0.1 \%$ SDS), one of the gels was stained with $0.5 \%$ colorimetric Coomassie brilliant blue (Sigma, USA) as a quantitative control and the other was transferred to the polyvinylidine difluoride (PVDF) membrane (Stratagene) and blocked with 5\% skimmed milk in PBST (100 mM sodium chloride, $80 \mathrm{~mm}$ disodium hydrogen phosphate, $20 \mathrm{~mm}$ sodium dihydrogen phosphate, $0.2 \%$ Tween $20, \mathrm{pH} 7.5$ ) solution at $4^{\circ} \mathrm{C}$ overnight. After washing with PBST and phosphate-buffered saline (PBS) buffer, the membrane was hybridized with the monoclonal anti-Bcl-2 primary antibody (Dako, Japan) at $37^{\circ} \mathrm{C}$ for $1 \mathrm{~h}$. The membrane was then washed and hybridized with the monoclonal anti-mouse IgG conjugated with horseradish peroxidase at $25^{\circ} \mathrm{C}$ for $1 \mathrm{~h}$ (KPL, USA). After washing, the membrane was exposed to radiographic film (Fuji, Japan) for $10 \mathrm{~min}$ after the enhanced chemiluminescence (ECL) detection reagents (Amersham, USA) were added.

\section{Flow cytometric analysis}

The cells harvested in PBS solution were centrifuged at $130 \mathrm{~g}$ for $5 \mathrm{~min}$ to remove the PBS; the cells were resuspended in $50 \mu \mathrm{l}$ of Hepes-buffered saline (HBS) solution [100 mM sodium chloride, $2.7 \mathrm{~mm}$ potassium chloride, $60 \mathrm{~mm}$ glucose, $10 \mathrm{~mm}$ Hepes, $0.1 \%$ bovine serum albumin (BSA), $\mathrm{pH}$ 7.3]. Cells were stained with $5 \mu \mathrm{l}$ of merocyanine $540\left(1 \mathrm{mg} \mathrm{ml}{ }^{-1}\right.$; Sigma $)$ and incubated for $10 \mathrm{~min}$ at room temperature. Samples were then analysed using the fluorescence-activated cell sorter (FACscan, Becton Dickinson, USA). Each result from 5000 cells was analysed by the analysis program CellFIT (McEvoy et al, 1988).

\section{DNA fragmentation analysis}

The harvested cells $\left(1 \times 10^{6}\right.$ per $100-\mathrm{mm}$ plate $)$ were washed with PBS and pelleted by centrifugation at $240 \mathrm{~g}$ twice. The cell pellets were then treated with lysis buffer [1\% NP-40 (Sigma) in $20 \mathrm{~mm}$ 
24
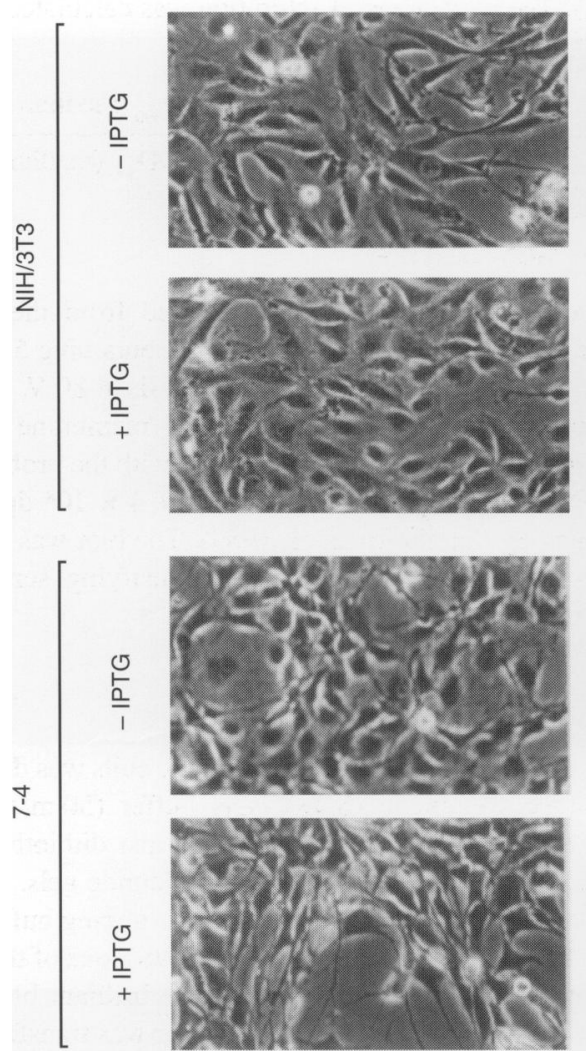

48
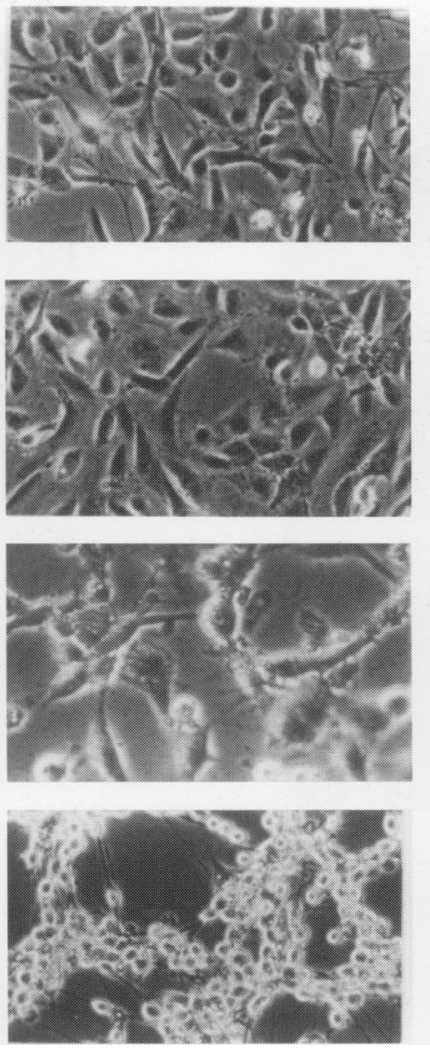

72
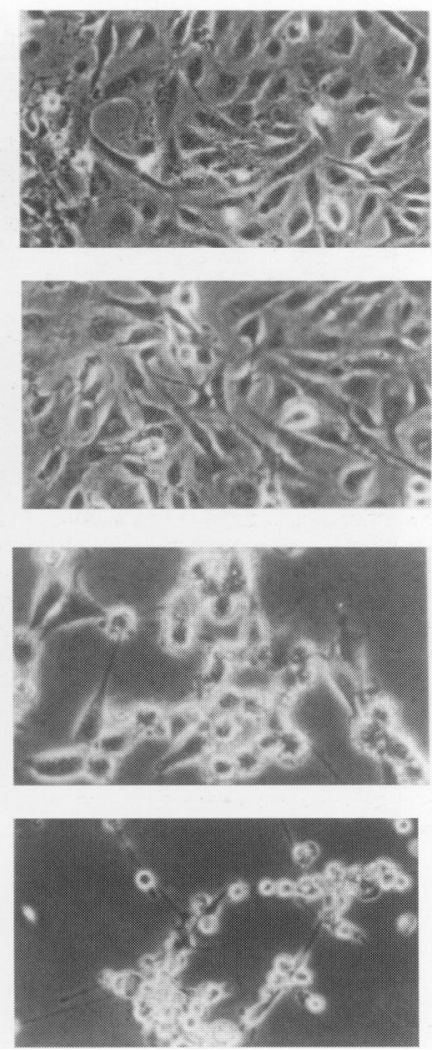

Figure 2 Effect of Ha-ras overexpression on morphological changes of NIH/3T3 and 7-4 cells. Subconfluent cells (1 $\times 10^{5}$ per $100-\mathrm{mm}$ plate) were cultured in $0.2 \%$ serum-containing medium for $24 \mathrm{~h}$, and IPTG $(2.5 \mathrm{~mm})$ was then added in the same medium as the onset of the time course investigation. Cells were photographed at 24,48 and $72 \mathrm{~h}$ after IPTG addition (100x)

ETD, $50 \mathrm{~mm}$ Tris-HCl, $\mathrm{pH} 7.5$ ] for $10 \mathrm{~s}$ and centrifuged for $5 \mathrm{~min}$ at $3100 \mathrm{~g}$ twice. The supernatant was brought to $1 \%$ SDS with RNAase A $\left(5 \mu \mathrm{g} \mu \mathrm{l}^{-1}\right)$ and kept at $56^{\circ} \mathrm{C}$ for $2 \mathrm{~h}$ followed by digestion with $2.5 \mu \mathrm{g}^{-1}$ proteinase $\mathrm{K}$ (Boehringer Mannheim) for at least $2 \mathrm{~h}$ at $37^{\circ} \mathrm{C}$. After addition of 0.5 vol $10 \mathrm{M}$ ammonium acetate, the DNA was precipitated with 2.5 vols $100 \%$ ethanol, resuspended in TE buffer (10 mM Tris- $\mathrm{HCl}, \mathrm{pH} 7.5,1 \mathrm{mM}$ EDTA) and separated by electrophoresis on a $1 \%$ TAE-agarose gel at $30 \mathrm{~V}$ for $8 \mathrm{~h}$. The DNA fragments were visualized by ethidium bromide staining (Hermann et al, 1994).

\section{CAT assay}

A $50-\mu \mathrm{g}$ cell lysate was incubated at $65^{\circ} \mathrm{C}$ for $10 \mathrm{~min}$ to denature the deacetylase activities. Twenty microlitres $\left(3.5 \mathrm{mg} \mathrm{ml}^{-1}\right)$ of acetyl coenzyme A (Sigma) and $2 \mu \mathrm{l}$ (sp. act. $=56 \mathrm{mCi} \mathrm{mmol}^{-1}$ ) of $\left[{ }^{14} \mathrm{C}\right]$ chloramphenicol (Amersham, UK) were added to the lysate and incubated at $37^{\circ} \mathrm{C}$ for $1 \mathrm{~h}$. To stop the reaction, $1 \mathrm{ml}$ of ethyl acetate (BDH, UK) was added to each sample and $0.9 \mathrm{ml}$ of the upper phase was transferred to the new Eppendorf tube and dried by a speed vac (Eyela, Japan). The pellet was resuspended in $10 \mu \mathrm{l}$ of ethyl acetate and dotted on the 25-mm thin-layer chromatography silica plate (Merck, Germany). The samples were spread by the chloroform-methanol mixture (95:5) (BDH, UK). The percentage of $\left[{ }^{14} \mathrm{C}\right] \mathrm{chloramphenol}$ acetylated was quantified by cutting the acetylated and non-acetylated spots and measuring the amount of radioactivity using the scintillation counter (LS 5000 TA, Beckman, USA).

\section{Luciferase and $\beta$-galactosidase activities assay}

The luciferase and $\beta$-galactosidase activities were determined by a Dual-Light luciferase and $\beta$-galactosidase reporter gene assay system (Tropix, USA). Briefly, equivalent amounts of protein lysates (the final volume was $10 \mu \mathrm{l}$ ) were mixed with buffer A, containing the reagents necessary for the luciferase reaction. Light signal from the luciferase enzyme present in the extract was measured immediately by a luminometer (Lumat, LB 9501, Germany) after the addition of buffer B containing luciferin and Galacton-plus. After another 30-min incubation, the light signal from the accumulated product of $\beta$-galactosidase and Galactonplus reaction is initiated by the addition of a light emission accelerator and measured using the luminometer.

\section{RESULTS}

\section{Ha-ras transgene was overexpressed in the transformants in the presence of IPTG under serum-deprived conditions}

The Ha-ras ${ }^{\text {val12 }}$ oncogene (GGC to GUC) cloned from the human T24 bladder carcinoma cell line (driven by an SV40 promoter with the $E$. coli lac repressor-binding operator) was introduced into 
A

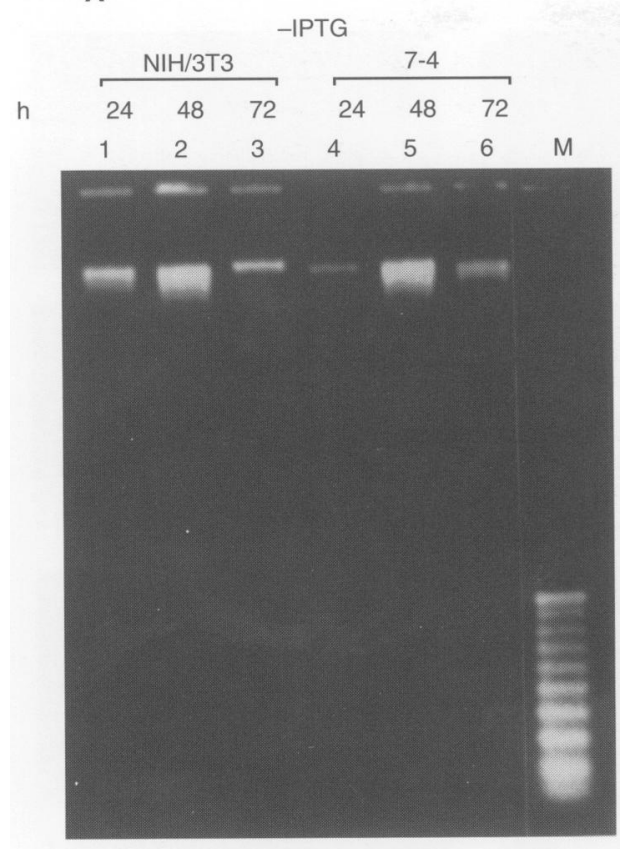

B

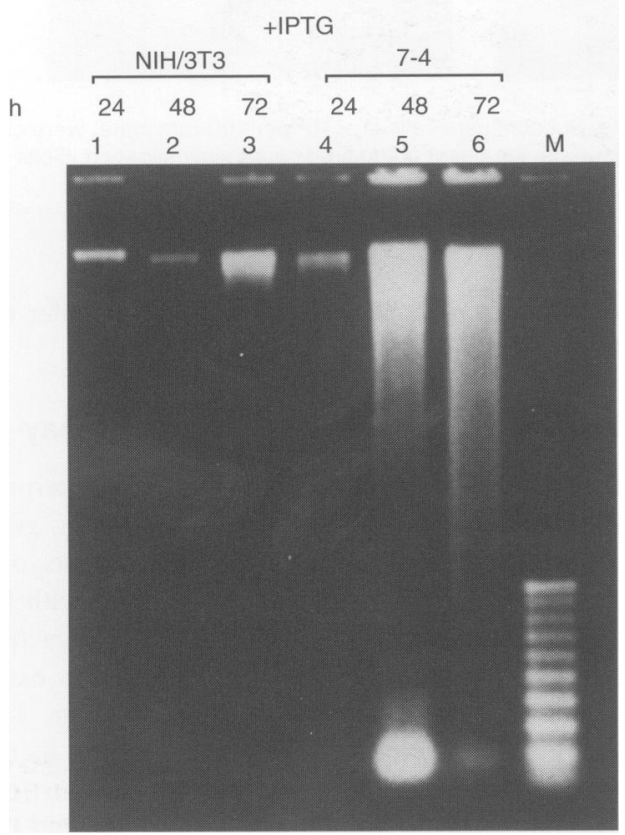

Figure 3 DNA fragmentation was detected in 7-4 cells while Ha-ras transgene was overexpressed by IPTG induction. The cells $\left(1.5 \times 10^{6}\right.$ per $150-\mathrm{mm}$ plate) were maintained in the medium containing $0.2 \%$ calf serum for $24 \mathrm{~h}, 2.5 \mathrm{~mm} \mathrm{IPTG}$ was then added to the same medium. Cells were harvested and DNA was extracted at 24,48 and $72 \mathrm{~h}$. (A) Without IPTG; (B) with IPTG; M, 1-kb DNA ladder marker

NIH/3T3 cells. Two cell lines, designated 212 and 7-4, have been established. The activated Ha-ras oncogene in these two cell lines can be overexpressed by IPTG induction under normal conditions (Liu et al, 1992). To ensure that the Ha-ras oncogene could also be overexpressed in the cells by IPTG induction under serum-deprived
A

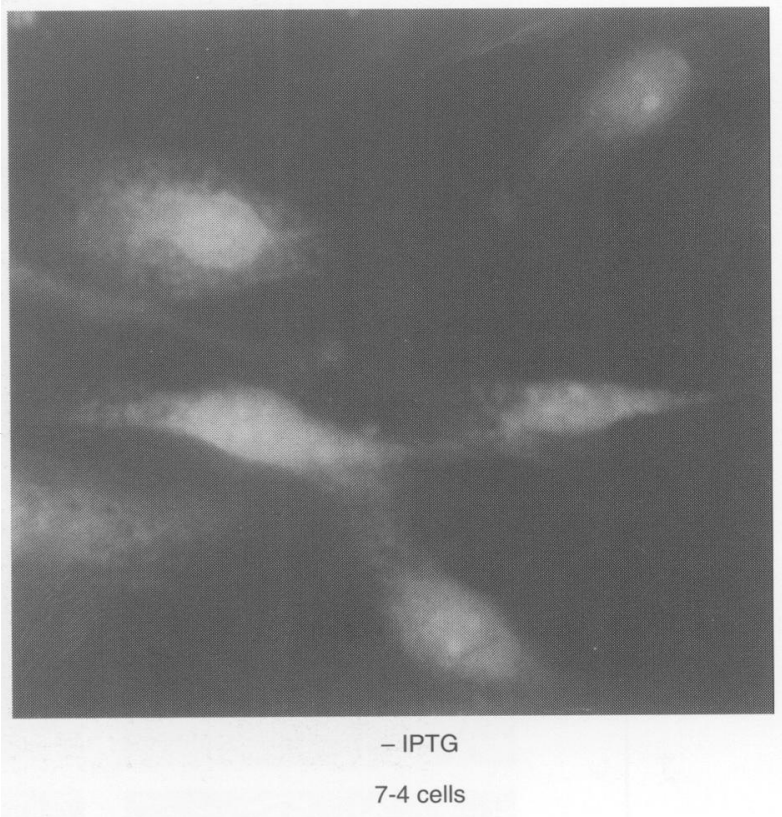

B

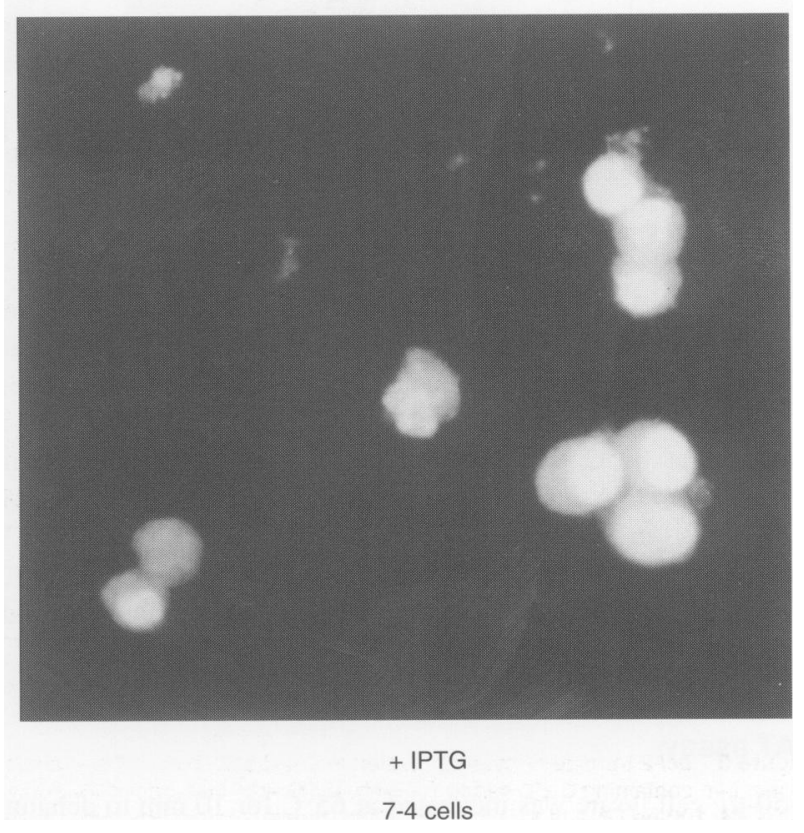

Figure 4 Apoptotic 7-4 cells were evidently stained by acridine orange. The cells $\left(1 \times 10^{3}\right.$ per slide) were maintained in the medium with $0.2 \%$ calf serum for $24 \mathrm{~h}$, IPTG was then added to overexpress $\mathrm{Ha}$-ras oncogene. The cells were fixed with $100 \%$ methanol and labelled with $1 \%$ acridine orange $48 \mathrm{~h}$ after IPTG induction $(200 \times)$. (A) 7-4 cells without IPTG; (B) 7-4 cells with IPTG

conditions, the assessment of basal and induced expression of the Ha-ras transgene in these cells was performed by Northern blot analysis. Very faint to undetectable Ha-ras signals in uninduced responsive cells (Figure 1, lanes 1, 3 and 5) and intense bands in induced cells (Figure 1, lanes 2 and 4 ) were detected $48 \mathrm{~h}$ after 
A

\begin{tabular}{|c|c|c|c|c|c|}
\hline \multicolumn{6}{|c|}{ - IPTG } \\
\hline & $7-4$ & & & 7-4-2 & \\
\hline 24 & 48 & 72 & 24 & 48 & 72 \\
\hline 1 & 2 & 3 & 4 & 5 & 6 \\
\hline
\end{tabular}

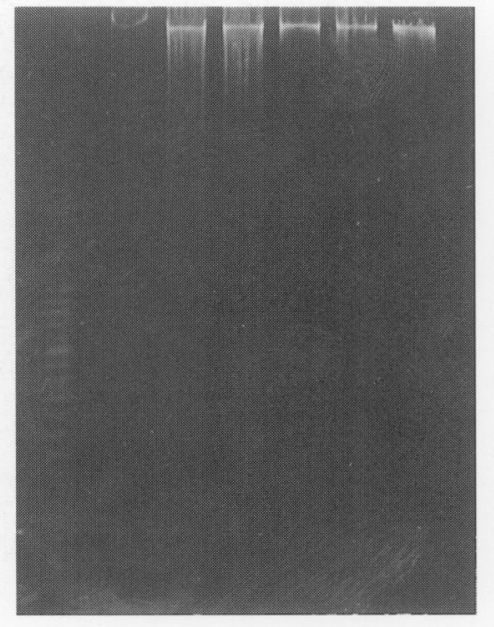

C 48

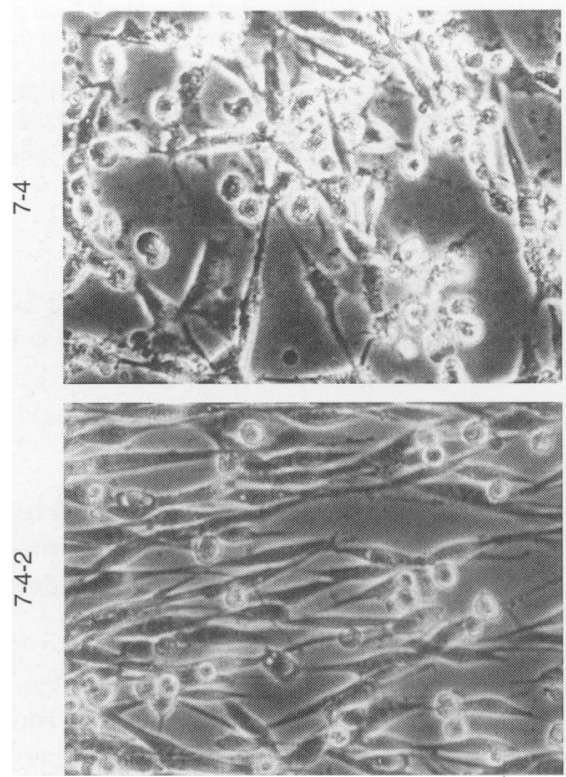

B

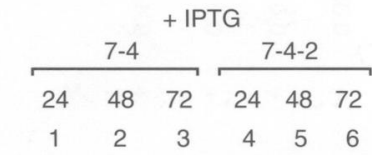

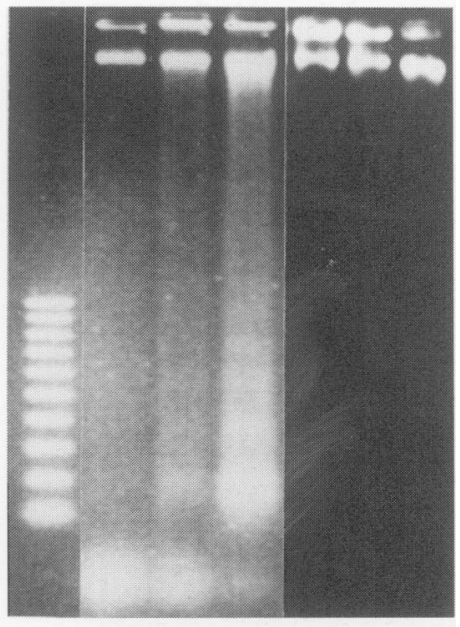

72
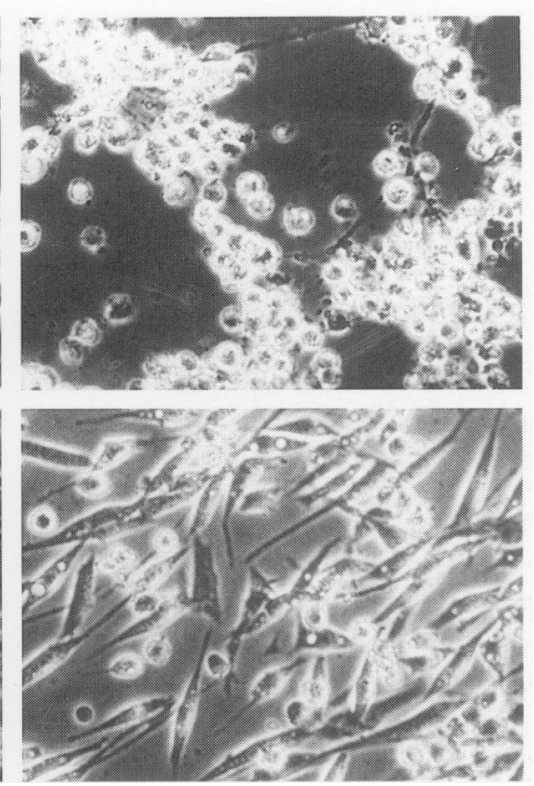

Figure 5 bct-2 transgene overexpression in 7-4-2 cells blocked apoptosis and altered the morphology. The cells (1.5 $\times 10^{6}$ per $150-\mathrm{mm}$ plate) were maintained in medium containing $0.2 \%$ serum for $24 \mathrm{~h}$, IPTG was then added as the onset of the time course investigation in the same medium. (A) Without IPTG; (B) with IPTG; M, 100-bp DNA ladder marker; (C) for morphological observation, subconfluent cells $\left(1 \times 10^{5}\right.$ per 100 -mm plate) were cultured in $0.2 \%$ serum containing medium for 2 days in the presence of IPTG, and then were photographed (100x)

IPTG induction. The increase in band intensity in 212 and 7-4 cells is $25 \times$ and $15 \times$, respectively, compared with their basal expression. Western blot analysis shows identical results (data not shown). The levels of Ha-ras overexpression and transforming characteristics of 212 and 7-4 cells are similar. Therefore, only 7-4 cells were used for the following analysis.

\section{7-4 cells died of apoptosis while the Ha-ras oncogene was overexpressed by IPTG induction under serum- deprived conditions}

The effects of Ha-ras overexpression on the cell cycle, morphological changes, viability and apoptosis of 7-4 cells were investigated. For cell cycle analysis, the cells were initially synchronized by $0.2 \%$ serum starvation for $24 \mathrm{~h}$ and then treated with IPTG and analysed at $24-\mathrm{h}$ intervals for 3 days in the $0.2 \%$ serum-containing 


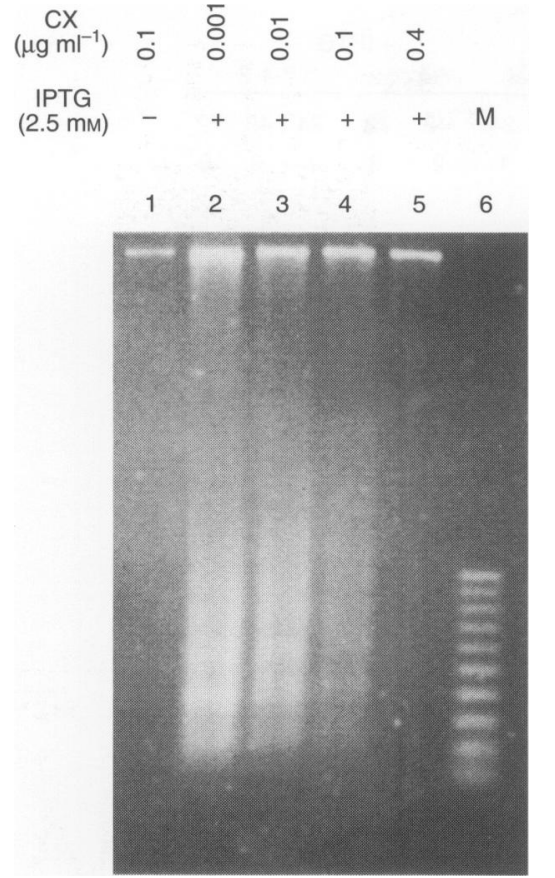

Figure 6 Cycloheximide blocked the apoptosis of 7-4 cells in a dosedependent manner. The cells $\left(1.5 \times 10^{6}\right.$ per $150-\mathrm{mm}$ plate $)$ were starved for $24 \mathrm{~h}$ in $0.2 \%$ serum containing medium, and IPTG was added for $6 \mathrm{~h}$. Cycloheximide was then added and incubated for another $72 \mathrm{~h}$ at the concentrations as indicated. The cellular DNA was isolated, and DNA fragmentation was analysed on a $1 \%$ agarose gel. Lane 6, 100-bp DNA marker

medium. The percentage of $7-4$ cells in $G_{0} / G_{1}$ phase was $48 \%$ in the absence of IPTG and dropped to 5\% in the presence of IPTG. Correspondingly, the percentage of 7-4 cells in S-phase was $48 \%$ in the absence of IPTG and raised to $90 \%$ in the presence of IPTG at $72 \mathrm{~h}$, indicating that the major 7-4 cell population accumulated in S-phase while the Ha-ras gene was overexpressed. In contrast, the percentage of cells in $\mathrm{G}_{2} / \mathrm{M}$ phase is constant at all the times tested (Table 1).

Morphological observation shows that NIH/3T3 and 7-4 cells exhibited similar flat and polygonal morphology at $24 \mathrm{~h}$ after treatment. The morphology of NIH/3T3 cells remained the same at all the times investigated. The morphology of uninduced 7-4 cells became more spindle-like and formed slender processes at 48 and $72 \mathrm{~h}$ after induction. However, IPTG-induced 7-4 cells started aggregating and showed contracted, rounded morphology in $48 \mathrm{~h}$. These cells formed small foci (containing 15-30 cells) and some of them started floating and died between 48 and $72 \mathrm{~h}$ (Figure 2).

To clarify whether the death of major 7-4 cells is apoptotic, the cells maintained in $0.2 \%$ serum-containing medium with or without IPTG induction for 48 and $72 \mathrm{~h}$ were analysed using DNA fragmentation analysis and acridine orange staining. Evident DNA fragmentation was detected in 7-4 cells maintained in $0.2 \%$ serumcontaining medium for 48 and $72 \mathrm{~h}$, while Ha-ras was overexpressed by IPTG induction (Figure 3B). IPTG per se or serum deprivation alone without Ha-ras overexpression could not stimulate apoptosis of all the cells tested (Figure 3A). Moreover, many 7-4 cells were rounded, and in about $80 \%$ of the cells $(797 \pm 5 /$ $1 \times 10^{3}$ cells) the chromatin was condensed and heavily stained by
A

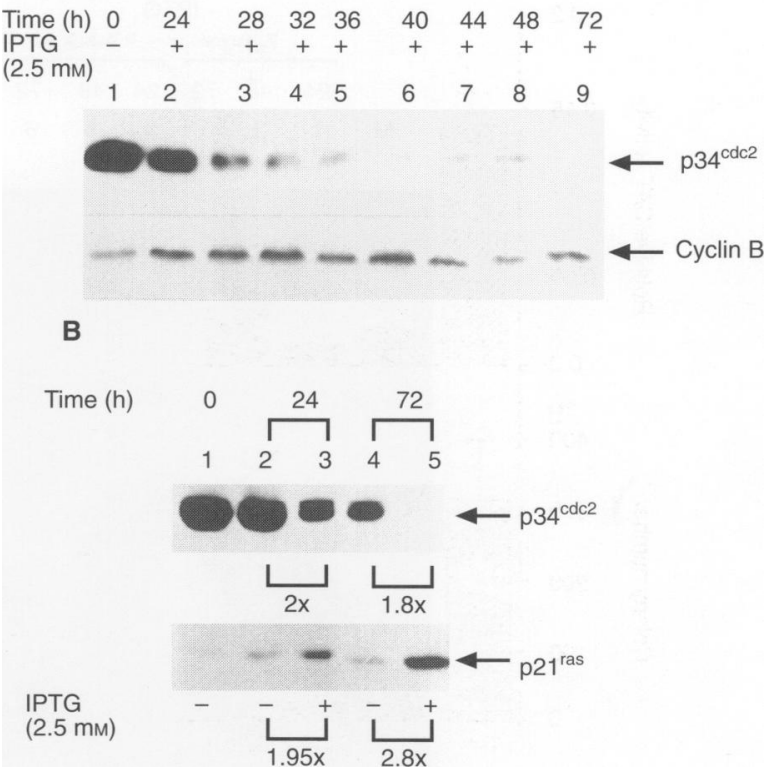

Figure 7 Western blotting demonstrates that the decreased levels of $p 34^{\text {cdc2 }}$ in 7-4 cells was related to serum starvation and $\mathrm{Ha}$-ras overexpression. The cells $\left(1 \times 10^{6}\right.$ per $100-\mathrm{mm}$ plate) were starved in $2 \%$ serum containing medium for $24 \mathrm{~h}$, IPTG was then added. Total protein lysates were extracted at the time as indicated. An aliquot $(50 \mu \mathrm{g})$ of the total protein was fractionated on the $12 \%$ SDS-polyacrylamide gel, and blotted onto the PVDF membrane. The expression of p34cac2, Cyclin B and Ras were detected by anti-p34codc2, anti-Cyclin B and anti-Ras antibodies followed by enhanced chemiluminescence detection using anti-mouse lgG

acridine orange in the presence of IPTG for $72 \mathrm{~h}$. However, 7-4 cells without IPTG induction showed normal flat morphology with very faint acridine orange staining. Less than $20 \%$ of the cells were apoptotic (178 $\pm 6 / 1 \times 10^{3}$ cells) (Figure 4).

\section{Apoptosis of 7-4 cells triggered by Ha-ras overexpression could be prevented by bcl-2 overexpression or cycloheximide treatment}

To test whether $b c l-2$ transgene overexpression could block Haras oncogene-induced apoptosis, the 7-4-2 cells that stably expressed the human $b c l-2$ gene (driven by an SV40 early promoter) were investigated. The expression of $b c l-2$ transgene at transcriptional and translational levels in 7-4-2 cells was confirmed (data not shown). DNA fragmentation in 7-4-2 cells could not be detected, suggesting that $b c l-2$ overexpression could block Ha-ras-induced apoptosis (Figure 5B, lanes 4-6). Neither IPTG nor serum starvation was sufficient to induce cell apoptosis without Ha-ras overexpression (Figure 5A). Moreover, 7-4-2 cells also showed spindle-like morphology. In contrast, 7-4 cells with significant DNA fragmentation started to contract and become round at $48 \mathrm{~h}$ and aggregated together within $72 \mathrm{~h}$ (Figure 5C).

While protein synthesis inhibitor cycloheximide (CX) was applied to 7-4 cells, Ha-ras-induced apoptosis was delayed in a CX dose-dependent manner, indicating that de novo protein synthesis is required for 7-4 cell apoptosis (Figure 6). Moreover, CX per se without IPTG induction could not trigger 7-4 cell apoptosis (Figure 6, lane 1). 
A
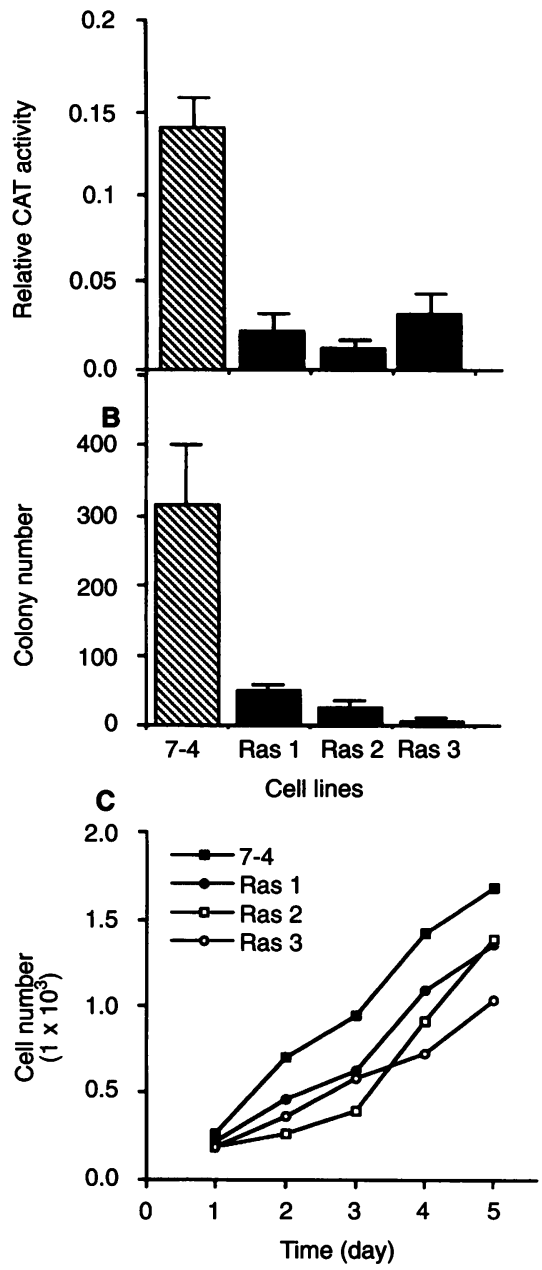

Figure 8 Dominant negative ras stably expressed in the derivatives of 7-4 cells blocked Ha-ras-induced AP-1 activity, and lowered the efficiency of colony formation as well as cell growth rate. (A) For AP-1 activity analysis, the 7-4 and Ras $1-3$ cell lines $\left(1 \times 10^{6}\right.$ per $100-\mathrm{mm}$ plate $)$ were transiently cotransfected with plasmid p5x collTRE-CAT $(3 \mu \mathrm{g})$ and pSG5lacZ $(0.5 \mu \mathrm{g})$. Plasmid p $5 x$ collTRE-CAT contains five tandem repeats of human collagenase promoter TRE that can be activated by binding to AP-1 (Wang et al, 1994). pSG5lacZ was used as an internal control for transfection efficiency. All the cells were maintained in the medium with $10 \%$ calf serum plus $2.5 \mathrm{~mm}$ IPTG for $48 \mathrm{~h}$, then the cells were harvested and analysed. CAT activity was presented as the following:

$$
\begin{aligned}
& \text { Relative CAT activity }=\frac{\text { counts in acetylated species }}{\text { (counts in acetylated species }} \\
& \text { (\% of conversion) (counts in acetylated species } \\
& + \text { in non-acetylated species) }
\end{aligned}
$$

(B) For colony formation analysis, the cells $\left(5 \times 10^{3}\right.$ per $35-\mathrm{mm}$ plate) were plated into six-well trays and cultured in $0.33 \%$ agar containing the medium supplemented with $10 \%$ calf serum in the presence of IPTG. Colonies were counted at day 10 . (C) For cell growth analysis, cells $\left(1 \times 10^{3}\right.$ per 96 wells) were plated into 96 -well trays in the medium with IPTG. The cell number was counted at a 24-h interval for 5 days by the microassay (Ito, 1984)

\section{The expression level of kinase p34cdc2 was decreased while 7-4 cells were grown in serum-deprived conditions accompanied by Ha-ras overexpression}

To understand the possible factors involved in the aberration of the 7-4 cell cycle and subsequent cell apoptosis, the kinases cyclin A, $B$ and $p 34^{\mathrm{cdc} 2}$ regulating the cell cycle from $G_{0} / G_{1}$ to $M$-phase were observed at the translational level.
A

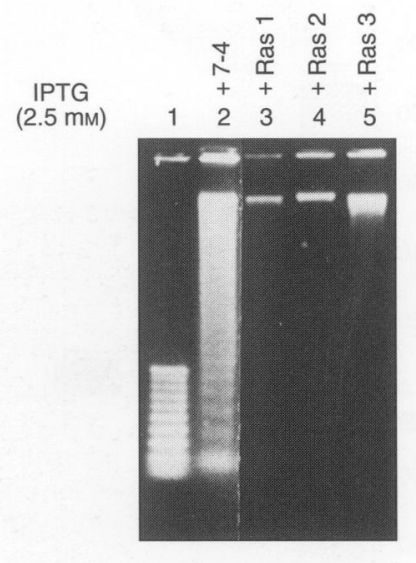

B

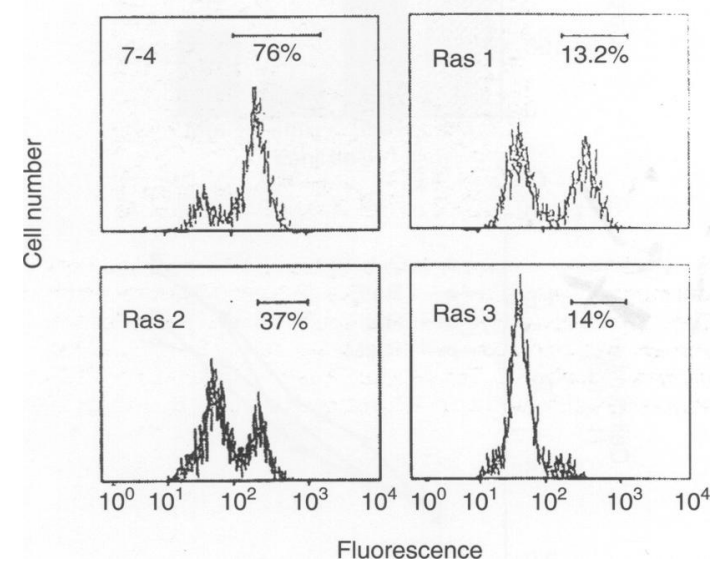

Figure 9 DNA fragmentation and apoptotic population were suppressed in 7-4 derivatives expressing dominant negative ras. (A) The cells $\left(1.5 \times 10^{6}\right.$ per $150-\mathrm{mm}$ plate) were maintained in $0.2 \%$ serum containing medium for $24 \mathrm{~h}$, then IPTG was added. Cellular DNA was extracted $48 \mathrm{~h}$ after treatment, and analysed on a $1 \%$ agarose gel. Lane 1, 100-bp DNA marker; lane 2, 7-4 cells with DNA fragmentation as a positive control; lanes $3-5$ are Ras $1-3$ cell lines expressing dominant negative ras. (B) The cells $\left(2 \times 10^{5}\right.$ per $35-\mathrm{mm}$ plate) were treated the same as in $A$. The cells were labelled with merocyanine 540 ( $50 \mu \mathrm{g} \mathrm{ml}^{-1}$; Sigma, USA) for $10 \mathrm{~min}$ in the dark, then analysed using the FACScan (Becton Dickinson, USA). Merocyanine 540, like Annexin V, can bind to the membrane phospholipid phosphatidylserine, which was translocated from inner face of the membrane to the surface of early apoptotic cells, and is used as the indicator of apoptosis. $y$-axis is the cell number; $x$-axis is the fluorescence intensity; bar indicates the percentage of apoptotic population

The treatment of the cells is the same as described above. Briefly, cell lysates were extracted at a 24 -h interval until $72 \mathrm{~h}$ after IPTG induction, and the expression levels of p34 ${ }^{\mathrm{cdc} 2}$, cyclin A and $B$ were investigated. Figure 7A shows the expression levels of p34 ${ }^{\mathrm{cdc} 2}$ and cyclin $\mathrm{B}$ using western blotting. Evidently, the p34 ${ }^{\mathrm{cdc} 2}$ protein levels were inversely decreased, whereas the time for IPTG treatment was increased under $0.2 \%$ serum-containing medium. Comparatively, the expression levels of cyclin B were unchanged. Similar to cyclin B, the expression level of cyclin A was unchanged as well (data not shown). The falling of $\mathrm{p} 34^{\mathrm{cdc} 2}$ expression either due to Ha-ras overexpression or due to serum deprivation or due to both was determined by administration of IPTG. Figure 7B demonstrates that serum deprivation alone could cause significant falling of p34 ${ }^{\mathrm{cdc} 2}$ (Figure 7B, lanes 1, 2 and 4), 
A
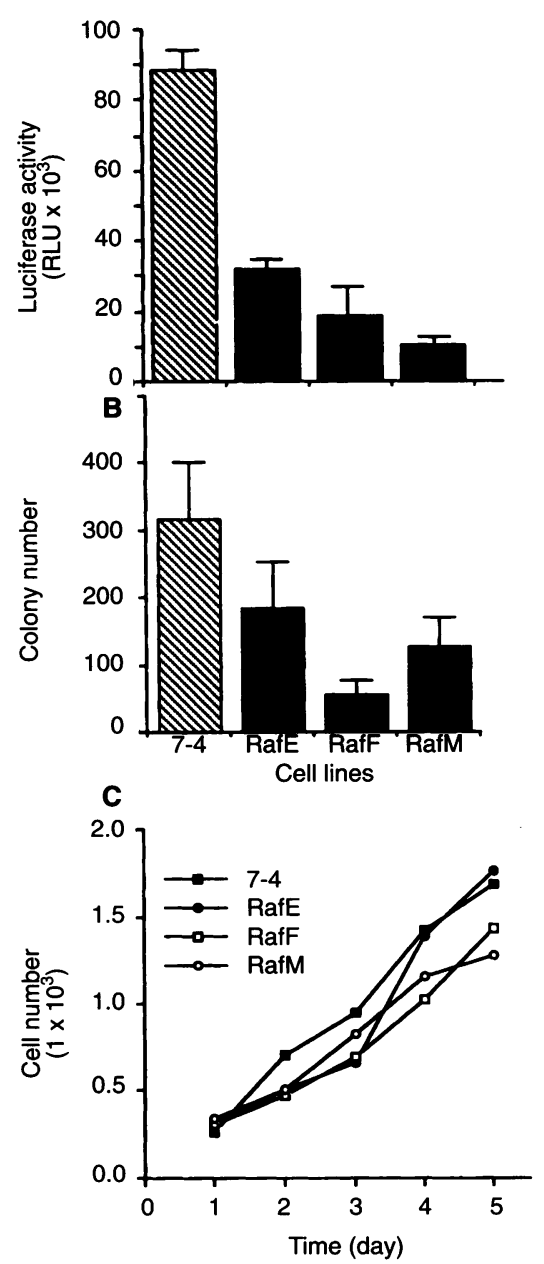

Figure 10 Dominant negative raf-1 expressed in the derivatives of 7-4 cells blocked Ha-ras overexpression induced Elk activity, and lowered the efficiency of colony formation and growth rate. (A) For Elk activity analysis, 7-4 and Raf E, $F$ and $M$ cells $\left(1 \times 10^{6}\right.$ per $100-\mathrm{mm}$ plate $)$ were co-transfected with pFAEIk $(1.5 \mu \mathrm{g})$, pFRLuc $(1.5 \mu \mathrm{g})$ and pSG5lacZ $(0.5 \mu \mathrm{g})$, which was used as an internal control for transfectin efficiency. All the cells were maintained in the medium with IPTG for $48 \mathrm{~h}$, then harvested and analysed for luciferase and $\beta$-galactosidase activities (see Materials and methods). (B) The procedures for colony formation and cell growth analysis are the same as described in Figure $\mathbf{8} \mathbf{B}$ and $\mathbf{C}$

and Ha-ras overexpression (1.95- to 2.8-fold) further enhanced this suppression by 1.8- to 2-fold (Figure 7B, lanes 2 and 3, 4 and 5). Moreover, the phosphorylation of $\mathrm{p} 34^{\mathrm{cdc} 2}$ was not affected by Ha-ras overexpression under serum-deprived conditions (unpublished data). The decrease in $\mathrm{p} 34^{\mathrm{cdc} 2}$ at the translational level seems to play an important role in disruption of the cell cycle.

\section{Dominant-negative ras and dominant negative raf-1 blocked Ha-ras overexpression-induced apoptosis at different signal transduction stages}

To ensure that Ha-ras indeed triggers the apoptosis of 7-4 cells, the dominant negative ras [in plasmid pZIPneoAsn 17 with a mutation at amino acid 17 (serine to asparagin)] was transfected into 7-4 cells to block Ras activity (Feig and Cooper, 1988). Three stable
A

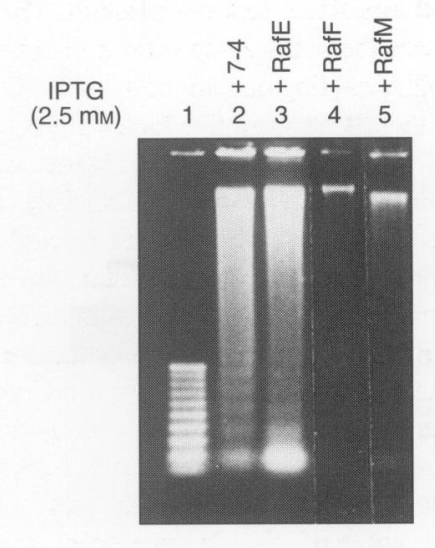

B

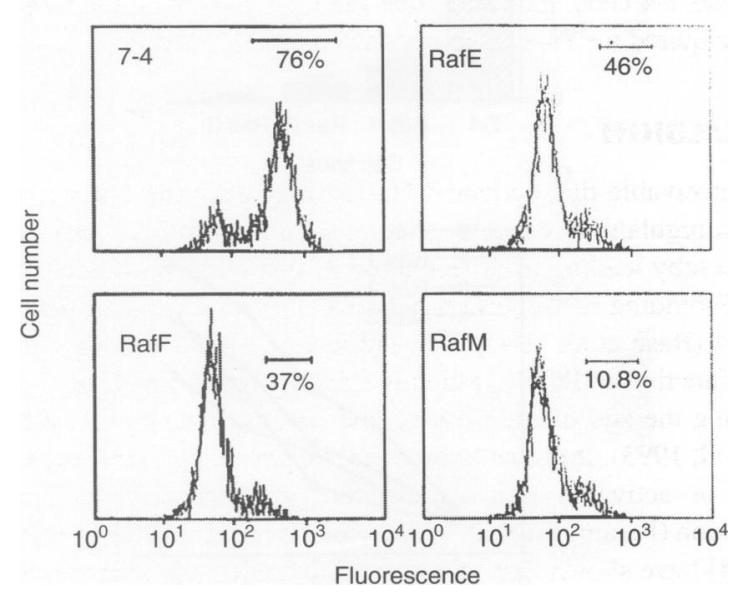

Figure 11 DNA fragmentation and apoptotic population were suppressed in 7-4 derivatives expressing dominant negative raf-1. Cell maintenance and treatment were the same as described in Figure 9. (A) DNA fragmentation analysis. (B) Quantification of apoptotic cells

transfectants Ras 1, Ras 2 and Ras 3 with higher levels of dominant negative ras expression show lower AP-1 activity (Figure 8A), lower efficiency of colony formation (Figure 8B) and slower cell growth rate (Figure 8C) compared with the parental 7-4 cells, indicating that dominant-negative ras effectively blocked Ras activity. AP- 1 consists of the members of the jun and the fos families, which can be activated by RAS; therefore, its activity can be used as the indicator of Ras activity. Moreover, the degree of DNA fragmentation and the population of apoptotic cells were all evidently decreased in these dominant-negative ras cell lines (Figure 9A and B), indicating that ras indeed plays a major role in 7-4 cell apoptosis.

Raf-1 is an effector of activated Ras and its downstream transducers are MAPK, Erk and Elk (Kauffmann-Zeh et al, 1997). To unveil whether ras-triggered apoptosis is through the raf-1 signalling pathway, the dominant negative raf-1 gene (in plasmid pRafC4B, with a deletion at $3^{\prime}$ end kinase domain) was transfected into 7-4 cells (Bruder et al, 1992). Three cell lines Raf E, Raf F and Raf M stably expressing the raf-1 gene were established (data not shown). To determine the activity of Raf-1, its downstream substrate Elk activity was measured by the PathDetect Elk-trans-reporter 
system (Stratagene). This reporting system contains a pFAElk fusion activator plasmid and a pFRLuc reporter plasmid. The fusion activator plasmid expresses the pathway-specific transactivator protein that consists of the DNA-binding domain of the yeast GAL 4 and the activation domain of the Elk transcription factor. Because this fusion activator pFAElk is phosphorylated and activated by Raf-1, its activity reflects the in vivo activation of this kinase and the corresponding signal transduction pathway. The Raf-1 activity, efficiency of colony formation and the rate of cell growth of Raf $F$ and Raf M were decreased to various degrees compared with their parental 7-4 cells, indicating that Raf activity was blocked by the dominant negative raf-1 (Figure 10A and C). Comparatively, Raf E showed much less efficiency in suppression of Raf activity, colony formation and cell growth. We found the mRNA level in Raf E cells is the lowest compared with the other two cells lines (data not shown). Correspondingly, the degree of DNA fragmentation and population of apoptotic cells in Raf $F$ and Raf $M$ were much lower than that in Raf $\mathrm{E}$ and 7-4 cells, indicating that the raf-1 signalling pathway is indeed required for 7-4 cell apoptosis (Figure 11A and B).

\section{Discussion}

It is conceivable that activated Ha-ras may alter the interactions between regulatory accessory factors such as Ras-GAP and RasGEF, thereby leading to deregulation of one or more members of the GTP-binding ras superfamily (Bokoch and Der, 1993), such as $\mathrm{ran} / \mathrm{TC} 4$ (Basu et al, 1992). The product of $\mathrm{ran} / \mathrm{TC} 4$ is necessary for the function of $\mathrm{RCCl}$, which is a gene product involved in coordinating the end of the S-phase and chromosome condensation (Ren et al, 1993). It is also known that inappropriate expression of normal or activated ras can interfere with normal cell cycle progression (Feramisco et al, 1984; Mulcahy et al, 1985). Denko et al (1994) have shown that selective induction of the activated Haras transgene with IPTG is sufficient to disrupt at least one cell cycle control point by stimulating serum-deprived 212 cells to progress from $G_{1}$ arrest into $S$-phase. All the data indicate that activated ras can facilitate the transition from $G_{1}$ to $S$-phase of the cell cycle. This phenomenon is consistent with our observation of 7-4 cells that accumulated in S-phase while activated Ha-ras was overexpressed by IPTG.

The disruption of the normal cell cycle that resulted in the death of the cells has been reported (Rubin et al, 1993). Meikrantz et al (1994) classified the death of S-phase-arrested cells in an asynchronous population into multiple forms of apoptosis. The correlation between S-phase arresting and apoptosis may explain that 7-4 cells with a major population of S-phase-arrested cells showed high mortality, significant DNA fragmentation and strong acridine orange staining. Such cell cycle disruption may result from either gene expression at the wrong time or aberrant expression of normal cell cycle kinases, including activation or inactivation (Rubin et al, 1993). Chen and Pan (1994) reported that in Xenopus oocytes, Ha-ras oncogene overexpression suppressed the activity but not the expression level of $\mathrm{p} 34^{\mathrm{cdc} 2}$, and subsequently led the cell to rest in M-phase. In our study, Ha-ras overexpression greatly suppressed $\mathrm{p} 34^{\mathrm{cdc} 2}$ expression level and led the cells to accumulate in S-phase.

Many factors may be involved in the process of Ha-ras-induced apoptosis, but the relationships largely remain unknown (Whyte and Evan, 1995). The possible mechanisms of Ha-ras overexpression-induced apoptosis in 7-4 cells are as follows: (a) overexpression of Ha-ras oncogene inactivates cell cycle-related kinases (such as the kinase p34 ${ }^{\mathrm{cdc} 2}$ ) (Girard et al, 1991); (b) Ha-ras overexpression shuts off the expression of 'survival' genes, such as $b c l-2$ in the absence of appropriate growth factors under serum depleted condition and guides cells to death; (c) the unknown factor that triggered the apoptotic pathway was specially activated in 7-4 cells (such as IRF-1) (Tanaka et al, 1994).

Overexpression of the $b c l-2$ gene blocked Ha-ras-induced apoptosis but had no effect on Ha-ras oncogene expression, indicating that its prevention of apoptosis is downstream in the Ha-ras signalling pathway (unpublished data). Moreover, Bcl-2 and p $21^{\text {ras }}$ molecules can be co-immunoprecipitated in Jurkat cells, and phosphorylation of the $\mathrm{Bcl}-2$ protein is involved in the prevention of cell apoptosis (Chen and Faller, 1996). However, the precise mechanism by which the $b c l-2$ gene prevents Ha-ras-induced apoptosis remains to be determined.

Our results from (a) selective overexpression of activated Haras oncogene by IPTG; and (b) specific blockage of Ras activity by dominant negative ras or dominant negative raf clearly demonstrate that overexpression of activated Ha-ras indeed induces 7-4 cells apoptosis under serum-deprived conditions. Activated Haras-induced apoptosis was also detected in the other transformant 212 cells. But the degree of apoptosis was less severe compared with 7-4 cells, indicating that factors other than Ha-ras activation may also be involved. However, our observation that 7-4 cells proceeded with apoptosis without c-myc overexpression (unpublished data) is different from Kauffmann-Zeh's report that both Ha-ras and c-myc are overexpressed in the apoptosis of the fibroblasts (Kauffmann-Zeh et al, 1997). This contrasting result indicates that c-myc overexpression is not an inducing factor but an end-point response of Ha-ras-induced apoptosis.

The effect of serum starvation on long-term viability of the cells was observed by measuring the percentage of dye excluding cells that were stained with $0.04 \%$ trypan blue at a 24 -h interval. We found that, $72 \mathrm{~h}$ after starvation, the percentage of viable 7-4 cells is $88 \%$ in the absence of IPTG and drops to $50 \%$ in the presence of IPTG compared with NIH/3T3 cells (100\%), indicating that NIH/3T3 and 7-4 cells could stand long-term starvation (unpublished data). Ha-ras gene overexpression makes 7-4 cells more vulnerable to serum deprivation and induces them to apoptosis.

The uncertainty whether nutrient deficiency caused by serum starvation may induce cell apoptosis was clarified by growing the cells in the medium supplemented with $10 \%$ AC-2 (Valio, Finland; collostrum, a serum substitute). We found that NIH/3T3 and a lung carcinoma cell line H2981 could grow normally in this kind of medium (unpublished data). In contrast, 7-4 cells with Ha-ras overexpression maintained in the same conditions underwent apoptosis, indicating that serum depletion causing nutrient deficiency is not a determining factor of apoptosis. It is consistent with Kulkarni's report that serum starvation only caused minor cell apoptosis (Kulkarni and McCulloch, 1994). The amount of certain growth factors such as IGF-1 in either $0.2 \%$ serum or $10 \%$ AC-2 may be critical to determine cell survival or death. A detailed study is under way.

Dominant negative raf-1 blocked the Raf-1-MAPK pathway and prevented apoptosis of 7-4 cells, indicating that Ha-ras-induced apoptosis needs Raf-1-MAPK pathway activity, which is consistent with Kauffmann-Zeh's observation that Raf-1-MAPK is an apoptotic pathway. It seems that the Raf-MAPK pathway is a common pathway for both proliferation and apoptosis. We hypothesize that in $\mathrm{NIH} / 3 \mathrm{~T} 3$ fibroblasts while Ha-ras was overexpressed, serum starvation as an exogenous stress will turn on the apoptotic signal through 
Ha-ras and raf-1 signalling pathways. The fate of the cells will then be executed by downstream specific nuclear transactivators, which are formed after Ha-ras activation and activated through dimer formation (such as the pairing of the members of jun and for families) that activate either survival genes or apoptotic genes. Ha-ras overexpression activated downstream from the expression of apoptotic-related genes was sustained by a protein synthesis inhibitor cycloheximide study, which delayed 7-4 cell apoptosis.

In conclusion, our study demonstrates that Ha-ras val12 overexpression without c-myc overexpression can trigger cell apoptosis This apoptosis may use the Raf-1-MAPK pathway to synthesize specific nuclear factors and subsequently to turn on apoptotic-related genes. These events were confirmed by the studies of dominantnegative ras, raf-1, cycloheximide and $b c l-2$ gene overexpression.

The relationship between Ha-ras ${ }^{\text {val12 }}$ oncogene overexpression and cell apoptosis observed in our laboratory will shed light on the understanding of Ha-ras oncogene-related apoptosis and aid in unveiling the factors that lead tumour cells with the expression of activated Ha-ras oncogene to programmed cell death.

\section{ACKNOWLEDGEMENTS}

The authors thank Dr SL Chen and Dr YP Tsao for providing technical assistance in cyclin A and B analysis. This work was supported by grants from the National Science Council, Taiwan (NSC83-0412-B006-055 and NSC85-2331-B006-014).

\section{REFERENCES}

Arends MJ, McGregor NJ, Brown EJ and Wyllie AH (1993) Susceptibility to apoptosis is differentially regulated by c-myc and mutated Ha-ras oncogenes and is associated with endonuclease availability. Br J Cancer 68: 1127-1133

Arends MJ, McGregor NJ and Wyllie AH (1994) Apoptosis is inversely related to necrosis and determines net growth in tumors bearing constitutively expressed myc, ras, and HPV oncogenes. Am J Pathol 144: 1045-1057

Barbacid M (1987) ras genes. Annu Rev Biochem 56: 779-827

Basu TN, Gutman DH, Fletcher JA, Glover TW, Collins FS and Downward J (1992) Aberrant regulation of ras proteins in malignant tumour cells from type 1 neurofibromatosis patients. Nature 356: 713-715

Bokoch GM and Der C (1993) Emerging concepts in the Ras superfamily of GTPbinding proteins. FASEB $J$ 7: 750-759

Bruder JT, Heidecker G and Rapp UR (1992) Serum-, TPA-, and ras induced expression from AP-1/Ets-driven promoters requires raf-1 kinase. Gene Dev 6: 545-556

Chen CT and Pan BT (1994) Oncogenic ras stimulates a 96-kDa histone H2b kinase activity in activated Xenopus egg extracts. J Biol Chem 269: 28034-28043

Chen CY and Faller DV (1996) Phosphorylation of Bcl-2 protein and association with p21 Ras in Ras-induced apoptosis. J Biol Chem 271: 2376-2379

Denko NC, Giaccia AJ, Stringer JR and Stambrook PJ (1994) The human Ha-ras oncogene induces genomic instability in murine fibroblasts within one cell cycle. Proc Natl Acad Sci USA 91: 5124-5128

Downward J (1992) Regulatory mechanisms for ras proteins. Biotechnology 14: 177-184

Ducoeur L, Wyborski DL and Short JM (1993) Control of gene expression in eucaryotic cells using the lac repression system. Strat Mol Biol 5: 70-72

Feig LA and Cooper GM (1988) Inhibition of NIH/3T3 cell proliferation by a mutant ras protein with preferential affinity for GDP. Mol Cell Biol 8: $3235-3243$
Feramisco JR, Gross M, Kamata T, Rosenberg M and Sweet RW (1984) Microinjection of the oncogene form of the human H-ras (T-24) protein results in rapid proliferation of quiescent cells. Cell 38: 109-117

Fernandez A, Fosdick LJ, Marin MC, Diaz C, McDonnell TJ, Ananthaswamy HN and McConkey DJ (1995) Differential regulation of endogenous endonuclease activation in isolated murine fibroblast nuclei by ras and $b c l-2$. Oncogene 10: 769-774

Girard F, Strausfeld U, Fernandez A and Lamb NJC (1991) Cyclin A is required for the onset of DNA replication in mammalian fibroblasts. Cell 67 : 1169-1179

Gulbins E, Bissonnette R, Mahboubl A, Martin S, Nishioka W, Brunner T, Baier G, Baier-Bitterlich G, Byrd C, Lang F, Kolesnick R, Altman A and Green D (1995) FAS-induced apoptosis is mediated via a ceramide-initiated RAS signaling pathway. Immunity 2: 341-351

Hermann M, Lorenz HM, Voll R, Gruk M, Woith W and Kalden JR (1994) A rapid and simple method for the isolation of apoptotic DNA fragments. Nucleic Acids Res 22: 5506-5507

Ito M (1984) Microassay for studying anticellular effects of human interferons. $J$ Interferon Res 4: 603-608

Jimenez B, Adrends M, Esteve P, Perona R, Sanchez R, Cajal SR, Wyllie A and Lacal JC (1995) Introduction of apoptosis in NIH3T3 cells after serum deprivation by overexpression of $r h o-p 21$, a GTPase protein of the ras superfamily. Oncogene 10: 811-816

Kauffmann-Zeh A, Rodriguez-Viciana P, Ulrich E, Gilbert C, Coffer D, Downward J and Evan G (1997) Suppression of c-myc-induced apoptosis by Ras signalling through DI(3)K and PKB. Nature 385: 544-548

Kulkarni GV and McCulloch (1994) Serum deprivation induces apoptotic cell death in a subset of Balb/c 3T3 fibroblasts. J Cell Sci 107: 1169-1179

Liu HS, Scrable H, Villaret DB, Lieberman MA and Stambrook PJ (1992). Control of Ha-ras-mediated mammalian cell transformation by Escherichia coli regulatory elements. Cancer Res 52: 983-989

McEvoy L, Schlegel RA, Williamson P and Buono BJ (1988) Merocyanine 540 as flow cytometric probe of membrane lipid organization in leukocytes. J Leukocyte Biol 44: 337-344

Meikrantz W, Gisselbrecht S, Tam SW and Schlegel R (1994) Activation of cyclin A-dependent protein kinases during apoptosis. Proc Natl Acad Sci USA 91: 3754-3758

Mulcahy LS, Smith MR and Stacey DW (1985) Requirement for ras proto-oncogene function during serum-stimulated growth of NIH 3T3 cells. Nature 313: 241-243

Ren M, Drivas G, D'Eustachio P and Rush MG (1993) Ran/TC4: a small nuclear GTP-binding protein that regulates DNA synthesis. J Cell Biol 120: 313-323

Rubin LL, Philpott KL and Brooks SF (1993) The cell cycle and cell death. Curr Biol 3: 391-194

Sakai N, Ogiso Y, Fujita H, Watari H, Koike T and Kuzumaki N (1994) Induction of apoptosis by a dominant negative $\mathrm{H}-$ ras mutant (116Y) in K562 cells. Exp Cell Res 215: 131-136

Sambrook J, Fritsch EF and Maniatis T (1989) Molecular Cloning: A Laboratory Manual. Cold Spring Harbor Laboratory Press: Cold Spring Harbor, NY

Tanaka N, Ishihara M, Kitagawa M, Harada H, Kimura T, Matsuyama T, Samphier MS, Aizawa S, Mak TW and Taniguchi T (1994) Cellular commitment to oncogene-induced transformation or apoptosis is dependent on the transcription factor IRF-1. Cell 77: 829-839

Tsujimoto Y (1989) Overexpression of the human BCL-2 gene product results in growth enhanceent of Epstein-Barr virus-immortalized B cells. Proc Natl Acad Sci USA 86: 1958-1962

Wang HG, Millan JA, Cox AD, Der CJ, Rapp UR, Beck T, Zha H and Reed JC (1995) R-Ras promotes apoptosis caused by growth factor deprivation via a Bcl-2 suppressible mechanism. J Cell Biol 129: 1103-1114

Wang WB, Bikel I, Marsilid E, Newsome D and Livingston DM (1994) Transexpression of RNA polymerase II promoters by the simian virus 40 small $t$ antigen. $J$ Virol 68: 6180-6187

Whyte M and Evan G (1995) The last cut is the deepest. Nature 376: 17-18 